\title{
Polyartistic Potential of Music Theory Subjects in Training Music Teachers
}

\author{
Komarovska Oksana \\ ORCID https://orcid.org/0000-0002-3679-9673 \\ Doctor of Sciences in Pedagogy \\ Head of Aesthetic and Art Education Laboratory of the Institute of \\ Problems on Education of the National Academy of Educational Sciences of \\ Ukraine
}

Xia Gaoyang

ORCID https://orcid.org/0000-0002-2871-9952

Postgraduate student (China)

Dragomanov National Pedagogical University (Ukraine, Kyiv)

\begin{abstract}
The article is devoted to the theoretical analysis of polyartistic content of musicology subjects in the professional training of future music teacher. The relation between musical-historical and musical-theoretical (in the narrow sense) disciplines has been revealed. The author determines that courses of music history and analysis of musical works are primarily polyartistic. The course History of music is determined as an integral part of the subjects of solfeggio, harmony, polyphony etc. The top of hierarchy of musicology disciplines is an analysis of musical works. Musical analysis is, essentially, the attempt to bridge the gap between students' intuitions about music and their conscious knowledge of it. In analysing works that students feel to be intrinsically worthwhile they are trying to correlate their subjective responses with observable properties in the music.

The initial methodological viewpoints of implementation of the polyartistic potential of musicaltheoretical training music teacher have been considered. The purpose of the article is to reveal the pedagogical potential of polyartistic activities in socio-communicative development of future Music teachers which is interpreted in the context of globalization, cultural development of a modern society. The necessity of the developmental potential implementation of polyartistic phenomena in order to develop of the holistic person is proved. It is defined the essence of concepts "polyartistic" and "multicultural", which are interpreted in the context of globalization, cultural development of a modern society.

Key words: future Music teacher, polyartistic training, musical-theoretical disciplines, history of music, analysis of musical works.

Актуальність проблеми. Питання поліхудожньої підготовки педагога-музиканта та учнів у системі загальної освіти інтенсивно розробляється впродовж останніх десятиліть (Л. Масол, Т. Рейзекінд, Л. Савенкова, Г. Шевченко, Б. Юсов). Упровадження
\end{abstract}


інтегративної мистецької освіти в Україні, де навчається автор статті (Л. Аристова, О. Боблієнко, Л. Масол), потребує готовності вчителя музики до оволодіння методиками, технологіями поліхудожнього навчання та власної поліхудожньої освіченості. Для китайської освіти взаємодія мистецтв, що базується на поліхудожності, має ментальне підгрунтя, а єдність мистецтв закладена у національні традиції.

Музично-теоретична підготовка вчителя музики постійно перебуває в полі уваги (М. Калашник, Ван Яюєци, К. Васильковська, С. Коробецька, Ю. Локарєва,

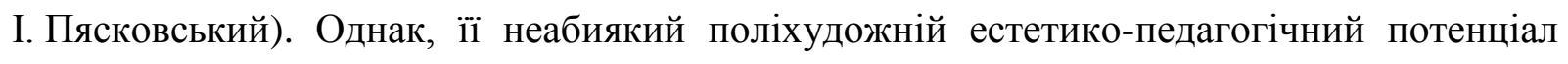
поки що обгрунтований недостатньо.

Мета статті - розкрити поліхудожній потенціал музично-теоретичних дисциплін (МТД) як чинника фахової підготовки студентів-музикантів педагогічних університетів.

Виклад основного матеріалу. У процесі фахової підготовки студенти-музиканти педагогічних університетів опановують комплекс музикознавчих дисциплін:музичноісторичні (історія музики (охоплює розділи вітчизняної і зарубіжної музики минулого і сучасності, різних стильових епох, національних культур), музичне народознавство); власне музично-теоретичні (сольфеджіо, елементарна теорія музики, гармонія, поліфонія, інструментознавство, аранжування, аналіз музичних творів). У поліхудожній підготовці стрижневу роль відіграє історія музики (IM), що інтегрує досвід 3 елементарної теорії музики, сольфеджіо, гармонії, поліфонії: через вивчення теорії в широкому розумінні уможливлюється занурення у стильові особливості музичної мови, а музичні стилі як квінтесенція втілення музичної образності пізнаються в історичному ракурсі. Суто теоретичні дисципліни закладають основи музично-теоретичної грамотності, формують уміння цілісного аналізу твору як художнього феномену. Вивчення історії музики акумулюється під час вивчення курсу аналізу музичних творів $(A M T)$, який є верхівкою піраміди музикознавчих дисциплін і для якого фундаментом слугує саме курс IM як інтегральний. Відтак, у системі музично-теоретичної підготовки IM та АМТ є дисциплінами первинно полі художніми.

Отже, МТД розуміємо як ієрархію дисциплін, через взаємодію яких найбільш цілеспрямовано розкривається поліхудожній потенціал. Первинну основу музичнотеоретичної підготовки у векторі поліхудожності складають дисципліни, що безпосередньо спрямовані на розвиток у студентів музичних здібностей; далі ті, що 
домінантні у формуванні музичного мислення, дослідницької здатності, чуття стилю, художнього смаку, навичок сприймання, фантазії, уяви (тобто IM та AMT).

Проектуючи вивчення МТД у поліхудожній контекст, розуміємо, що він охоплює різновекторне синтезування засобів різних видів мистецтва, спрямованих на розуміння музичної образності, оскілки стрижнем підготовки для майбутнього вчителя музики постає багатогранне опанування саме музичного твору. Зазначимо, що єдиної класифікації мистецтв, в естетико-філософській думці поки немає. Тому спираємось на праці філософів [2; 6], мистецтвознавців [1; 5], педагогів мистецтва $[7 ; 8 ; 6 ; 10 ; 14]$, які розкривають важливу для реалізації полі художнього підходу природу синтезу мистецтв.

Маємо справу переважно з музикоцентричною інтеграцією або синтезом мистецтв [12; 13], центром тяжіння в якому є музичний складник. Відтак, відзначимо опорні позиції виявлення та реалізації поліхудожнього потенціалу IM.

По-перше, опанування майбутніми вчителями музики змісту IM спрямоване на художнє пізнання творів у культурологічному та історико-хронологічному ракурсі. Кожне музичне явище розглядається в історико-культурному контексті певної епохи та певної країни (регіону світу) і має вивчатися поряд 3 творами інших мистецтв i встановленням смислових, образних, стильових зв 'язків з ними.

По-друге, твори, які вивчаються IM, належать різним жанрам. Але в контексті поліхудожньої підготовки логічно виокремити так звані синтетичні. Йдеться про твори музичного театру - опери, балети, оперети, мюзикли. Традиційно в IМ увага звертається на особливості їхнього музичного складника (музична драматургія, образність, вокальний та оркестровий компоненти), тобто твір вивчається не як багатошаровий текст для сценічного втілення, а як суто музичний. На жаль, цілісний сценічний образ, аналіз можливих сценічних інтерпретацій залишається поза увагою.

По-третє, для поліхудожньої підготовки важливе значення має вивчення творів 3 програмовою основою (літературною, живописною, історичною, філософською), яка неминуче викликає міжмистецькі асоціації, активізує синестезійні відчуття з живописом, графікою, скульптурою, архітектурою, сюжетами літератури, історичними постатями $\mathrm{i}$ подіями тощо.

По-четверте, враховуємо, що значна частина світового музичного доробку створена для драматичного театру, екранних мистецтв або ж використовується 
режисерами в театрі або на екрані, супроводжує різноманітні життєві події, створюючи смисловий підтекст. Сам факт такого використання музичних творів викликає необхідність осмислення їх в іншій художньо-образній ситуації і в зіставленні 3 виразними засобами інших мистецтв.

Нарешті, n`ята позиція, - твори, які залишаються в суто музичних образних та мовленнєвих межах, але для поглиблення емоційного осягнення яких можливо залучати інші мистецтва, наприклад, для зіставлення вирішення певного сюжету засобами різних мистецтв, у процесі виконання творчих завдань зі створення літературно-музичних композицій, сценаріїв, які «озвучуються» музикою і супроводжуються зоровим рядом тощо.

Поліхудожній потенцііал АMT збігається із зазначеним щодо IM, за винятком того, що не є обов’язковою історико-хронологічна послідовність. Натомість у поясненні закономірностей музичної розвитку, опанування предмету спираємось на досвід, здобутий майбутнім учителем музики з IM.

Вивчення IM та АМТ передбачає й оволодіння ключовими поняттями, що є спільними для всіх мистецтв (художній образ, стиль, жанр, форма, композиція, динаміка, ритм тощо). Так, до «синтезуючих» механізмів відносять конкретно-предметну образність; музичний образ; музично-пластичний і зображально-пластичний жест; зображувальну деталь у зіставленні з динамікою руху образу; специфічні мовні та надмовні засоби; конкретизацію музичної образності та комп’ютерної віртуальності тощо [9].

Обидва курси мають двоєдине підгрунтя: 1) опора на внутрішні, міжмистецькі зв’язки; 2) «вихід» у суміжні дисципліни, опанування яких сприяє заглибленню і в музичний твір, і в твори інших мистецтв та у мистецьку палітру як цілісність (зв'язки 3 естетикою, мистецтвознавством, культурологією, психологією музики і музичної творчості та психологією інших видів художньої творчості); це вимагає вивчення мови інших мистецтв, що спрямовується і на аналіз творів, і на виконавську, педагогічну, просвітницьку, лекторську діяльність, на науковий пошук у сфері мистецтва. Повноцінна реалізація цього передбачає теоретичне, емпіричне і практично-творче оволодіння способами взаємодії засобів мистецтв для розуміння художнього образу [3; 4; 11$]$. 
Важливою для поліхудожньої підготовки э увідомлення спорідненості термінологічного тезаурусу. Наприклад, Л. Масол зазначає, що художній образ твору і поняття, які є основною категорією педагогіки мистецтв, взаємодоповнюють один одного: поняття мовби «просвітлюють логікою» образні уявлення, емоційні відчуття, інтуїтивні прозріння. Поняття з різних сфер можуть збігатися повністю чи частково, не збігатися взагалі, мати різний масштаб спільної царини перетину [4; 5]; в музиці $\epsilon$ специфічно-музичні та неспещифічно-музичні засоби, запозичені від інших мистецтв. Наприклад, ритм, гармонійність, пропорційність, рівновага, симетрія та асиметрія, динаміка та статика, контраст і нюанс, фактура та інші в одних мистецтва набувають статусу точного визначення, а в інших використовуються як образна метафора. До основних категорій з образотворчого мистецтва належать форма, колір, композиція, рисунок. Для музики - інтонація. Додамо: очевидними є паралелі між «фонізмом» у музиці і «колоритом» у живопису; лінією у графіці, мелодією, малюнком танцю; орнаментом у декоративному мистецтві і танці, орнаментальністю в музиці тощо.

Таким чином, поліхудожній потенціал МТД полягає в комплексному пізнанні музичних творів через розкриття: 1) універсальної здатності музики «притягувати», синтезувати інші мистецтва в новий художній результат - безпосередньо в різних формах синтезу, й опосередковано - через різного типу програмність; 2) унікальної (завдяки інтонаційній природі) здатності створювати емоційний контекст i підтекст для глибинного освоєння мови інших мистецтв і навпаки - розкривати свої підтексти через залучення впливу засобів інших мистецтв та їхнього цілісного осмислення; 3) об’ єктивної здатності бути драматургічною основою в синтетичних видах і жанрах, які поза музичним складником взагалі втрачають доцільність існування, що потребує від реципієнтів і творців такого синтезу особливої поліхудожньої чутливості і знань 3 музикознавства, мистецтвознавства та психології художнього сприймання різних мистецтв та їхнього синтезу; 4) притаманної лише музичним творам спроможності сповіщати елементи руху, інтонаційного розгортання іншим видам мистецтва в художньо-образній цілісності.

Найбільш дієвими іє такі первинно поліхудожні дисципліни, як IM та AMT, які спираються на здобутки майбутніх учителів музики під час вивчення інших, вузько теоретичних монохудожніх курсів. 
Висновки. Поліхудожня підготовка вчителя музики як реалізація відповідного потенціалу МТД не є самоціллю. Її орієнтиром постає формування фахівця з цілісною художньою свідомістю, здатного збагачувати в духовному напрямі власне життя i застосовувати досвід у роботі з майбутніми учнями та іншими людьми. Така діяльність $€$ одночасно умовою, метою і самим процесом духовної актуалізації та розвитку особистості [6, с. 78]. Таке розуміння поліхудожньої підготовки актуалізує вектор подальших досліджень - єдність особистісних надбань і готовність передавати досвід учням.

\section{References}

1. Asafiev B.V. Muzykalnaia forma kak protsess [Musical form as a process]. Leningrad: Musica, 1971. $376 \mathrm{p}$.

2. Kahan M. S. Morfologiia iskusstva [Morphology of art]. Leningrad: Iskusstvo, 1972. $440 \mathrm{p}$.

3. Komarovska O.A. Mystetska osvita: peredchuttia zmin ta hotovnist uchytelia do nykh [Artistic education: a premonition of change and a teacher's readiness for them.]. Mystetstvo ta osvita. 2017. No 3. P. 10-15.

4. Komarovska O.A. Khudozhno-inonatsiinyi prostir zhyttia yak dzherelo tsinnostei pidrostaiuchoi osobystosti [Artistic-intonational space of life as a source of values of personality's developing: psychological and pedagogical aspects]. Topical issues of education: Collective monograph. - Pegasus Publishing, Lisbon, Portugal, 2018. - P. 260-280.

5. Metodyka navchannia mystetstva u pochatkovii shkoli [Methodology of teaching Art in elementary school]: posib. dlia vchyteliv / L. Masol [ta in.]. Kharkiv: Vesta, vyd-vo «Ranok», 2006. $-256 \mathrm{p}$.

6. Oleksiuk O., Tkach M. Pedahohika dukhovnoho potentsialu osobystosti: sfera muzychnoho mystetstva [Pedagogy of spiritual potential of personality: sphere of musical art]: navch. posibnyk. Kyiv: Znannia Ukrainy, 2004. 264 p.

7. Pet'ko L. V. Robota nad pisneju v kursi anglijs'koi' movy jak odyn iz zasobiv profesijnoi' pidgotovky studentiv gumanitarnyh special'nostej VNZ [The song in English course as a means of training humanities majors university students']. Inozemni movy. 2011. No. 1. P. 44-48.

8. Pet'ko L. V. Formuvannya profesiyno orientovanogo inshomovnogo navchalnogo seredovishcha $v$ umovah universitetu dlya studentiv spetsialnosti «Muzichne mistetstvo» (na prikladi virsha Meri Hovitt «Pavuk i Muha») [Formation of professionally oriented foreign language teaching environment in the terms of university for students of Music Art specialty (on illustration of a poem «The Spider and the Fly» by Mary Howitt)]. Naukovi zapiski Berdyanskogo derzh. ped. un-tu: zb. nauk. pr. Issue 1. Berdyansk : FO-P Tkachuk O.V., 2016. P. 184-190.

9. Reizenkind T. Y. Suchasni naukovi metody piznannia u polikhudozhnii pidhotovtsi maibutnoho vchytelia muzyky [Modern scientific methods of knowledge in multi artistic training 
future Music teacher]. Naukovyi chasopys NPU im. M. P. Drahomanova. Seriia 14: Teoriia i metodyka mystetskoi osvity. 2010. Issue 9. P. 24-27.

10. Komarovska O. Art Pedagogics in the Context of Civilizational Change: On the Problems of Teacher Training / Professional Artistic Education and Culture within Modern Global Transformations; ed. by O.Oleksiuk. Cambridge: Cambridge Scholars Publishing. 2018. PP. 79-85.

11. Komarovska Oksana, Huang Hanjie. Readiness for Stage Partnership in VocalEnsemble Performance as a Vector in Professional Training Music Teacher. Intellectual Archive. Toronto: Shiny Word.Corp. (Canada). 2018. (September/October). Vol. 7. No. 5. PP. 66-74. (https://doi.org/10.32370/2018_09_7)

12. Pet'ko Lyudmila, Tkachova Christina. Ballet on Ice. Nauka i Studia ; redactor Fr.Antoni. Filologiczne nauki. Psychologia i Socjologia. Przemys`1 : Nauka i Studia, 2014. No 7 (117). P. 111-115.

13. Pet'ko Lyudmila, Akulenko Svetlana. Shakespeare. «Romeo and Juliet». Ballet Art. Nauka i Studia ; redactor Fr.Antoni. - Filologiczne nauki. Psychologia i Socjologia. Przemys`l : Nauka i Studia, 2014. No 7 (117). P. 89-95.

14. Shcholokova O.P. Art and pedagogical designing as a means of improvement of music teacher's professional preparing. Economics, management, law: socio-economical aspects of development: Collection of scientific articles. Vol. 2. Edizioni Magi, Roma, Italy. 2016. P. 265-268.

\section{Translation of the Title, Abstract and References to the Author's Language}

УДК [378: 78.08]: 781.2

Комаровська О., Ся Гаоян. Педагогічний потенціал музично-теоретичних дисциплін у поліхудожній підготовці учителів музики.

У статті подано теоретичний аналіз поліхудожнього змісту музикознавчих предметів у фаховій підготовці майбутнього вчителя музики. Розкрито взаємозв'язок музично-історичних та музично-теоретичних (у вузькому сенсі) дисциплін. Визначено, що курси історії музики та аналізу музичних творів $є$ первинно поліхудожніми. Курс історії музики позиціонується авторами як інтегральний стосовно предметів сольфеджіо, гармонія, поліфонія тощо. Показано, що верхівкою в ієрархії музикознавчих дисциплін у контексті поліхудожності є аналіз музичних творів. Розглянуто вихідні методичні позиції реалізації поліхудожнього потенціалу музично-теоретичної підготовки вчителя музики.

Ключові слова: майбутній учитель музики, полі художня підготовка, музичнотеоретичні дисципліни, історія музики, аналіз музичних творів.

\section{Лimepamypa}

1. Асафьев Б. В. Музыкальная форма как процесс. - Л. : Музыка, 1971. 376 с.

2. Каган М. С. Морфология искусства. Ленинград : Искусство, 1972. 440 с.

3. Комаровська О.А. Мистецька освіта: передчуття змін та готовність учителя до них. Мистецттво та освіта. 2017. № 3. С. 10-15. 
4. Комаровська О.А. Художньо-інонаційний простір життя як джерело цінностей підростаючої особистості. Topical issues of education: Collective monograph. Pegasus Publishing, Lisbon, Portugal, 2018. P. 260-280.

5. Методика навчання мистецтва у початковій школі : посіб. для вчителів /Л. Масол [та ін.]. Харків: Веста, вид-во «Ранок», 2006. 256 с.

6. Олексюк О., Ткач М. Педагогіка духовного потенціалу особистості: сфера музичного мистецтва. Київ: Знання, 2004. 264 с.

7. Петько Л. В. Робота над піснею в курсі англійської мови як один із засобів професійної підготовки студентів гуманітарних спеціальностей ВНЗ. Іноземні мови. 2011. № 1. С. 44-48.

8. Петько Л. В. Формування професійно орієнтованого іншомовного навчального середовища в умовах університету для студентів спеціальності «Музичне мистецтво» (на прикладі вірша Мері Ховітт «Павук і Муха»). Наукові записки Бердянського державного педагогічного університету. Педагогічні науки: зб. наук. пр. Вип. 1. Бердянськ: ФО-П Ткачук O.B., 2016. C. 184-190. URI http://enpuir.npu.edu.ua/handle/123456789/10075

9. Рейзенкінд Т. Й. Сучасні наукові методи пізнання у поліхудожній підготовці майбутнього вчителя музики. Науковий часопис НПУ імені М. П. Драгоманова. Серія 14 : Теорія і методика мистецької освіти. 2010. Вип. 9. С. 24-27.

10. Komarovska O. Art Pedagogics in the Context of Civilizational Change: On the Problems of Teacher Training / Professional Artistic Education and Culture within Modern Global Transformations; ed. by O.Oleksiuk. Cambridge: Cambridge Scholars Publishing. 2018. PP. 79-85.

11. Komarovska Oksana, Huang Hanjie. Readiness for Stage Partnership in VocalEnsemble Performance as a Vector in Professional Training Music Teacher. Intellectual Archive. Toronto: Shiny Word.Corp. (Canada). 2018. (September/October). Vol. 7. No. 5. PP. 66-74. (https://doi.org/10.32370/2018_09_7)

12. Pet'ko Lyudmila, Tkachova Christina. Ballet on Ice // Nauka i Studia ; redactor Fr.Antoni. Filologiczne nauki. Psychologia i Socjologia. Przemys`l : Nauka i Studia, 2014. No 7 (117). P. 111-115.

13. Pet'ko Lyudmila, Akulenko Svetlana. Shakespeare. «Romeo and Juliet». Ballet Art // Nauka i Studia ; redactor Fr.Antoni. Filologiczne nauki. Psychologia i Socjologia. Przemys`1 : Nauka i Studia, 2014. No 7 (117). P. 89-95.

14. Shcholokova O. P. Art and pedagogical designing as a means of improvement of music teacher's professional preparing. Economics, management, law: socio-economical aspects of development: Collection of scientific articles. Vol. 2. Edizioni Magi, Roma, Italy. 2016. P. 265-268. 